\title{
INITIATION AND CONTROL OF MEIOSIS AND FOLLICULAR GROWTH IN OVARIES OF THE MOUSE
}

\author{
T. G. BAKER and P. NEAL \\ Hormone Laboratory, Department of Obstetrics and Gynaecology, \\ University of Edinburgh, \\ Edinburgh, EH3 $9 E R(U . K$.
}

\section{SUMMARY}

Ovaries derived from fetal and neonatal mice of the Schofield strain (aged I4 days $p . c$. to $\mathrm{r}_{4}$ days $p$. p.) were maintained in organ culture for periods ranging from 2 to $\mathrm{I}_{4}$ days. Histological sections of these gonads were compared with controls that were fixed immediately after removal from coeval animals.

It was found that germ cells in fetal ovaries progress through meiotic prophase at the same rate in culture as they do in vivo, although the number of germ cells was reduced if the ovary was cultured through a critical period (days I 4 -I 8 p.c.). The development of the granulosa, thecal and stromal cells was retarded such that the ovary was reduced in size and the oocytes became crowded together.

The process of follicular growth was severely retarded in organ cultures devoid of gonadotrophic hormones. Neither FSH nor LH alone was capable of restoring the normal growth process, although each hormone improved various facets of the overall process. It would seem that FSH and LH need to be present together if the normal development of the pre-pubertal ovary is to be adequately maintained.

\section{IN'TRODUCTION}

In spite of the many studies that have been made of mammalian oogenesis, the mechanisms controlling the proliferation of oogonia, the onset of meiosis, and the early phases of follicular growth remain obscure. It is well established that the onset and timing of these processes differs between mammalian species and even between strains within one species (e. g. mouse). In some mammals the progression of germ cells through meiotic prophase is more or less synchronized (e. g. rat : see BAKER, I972), although in the majority of species asynchrony is the rule. It has been suggested that levels of endogenous gonadotrophic hormones play no part in the 
regulation of these processes, the controlling mechanism seemingly being genetically ' programmed '. This view derives largely from studies involving treatment of animals with gonadotrophic hormones, or from experiments involving hypophysectomy (see BEN-OR, I963; MAULÁON, I969). However the results of recent experiments involving the use of antiserum to gonadotrophins have shown that protein hormones may be essential at least for the initiation of normal follicular growth (EsHroLLUNENFELD and PETERS, I97I).

The present study was designed to investigate the possible role of gonadotro, phins in the development of the fetal and neonatal mouse ovary. Since hypophysectomy of fetal and juvenile mice is very difficult to carry out, their ovaries were maintained in an organ culture system which was devoid of protein hormones. The precise effects of gonadotrophins were assessed histologically by comparisons between treated versus untreated cultures and also with control gonads.

\section{MATERIALS AND METHODS}

Pregnant female mice of the Schofield albino strain were killed by cervical dislocation at intervals from the ${ }^{4}{ }_{4}$ th $\left(^{1}\right)$ day of pregnancy to full-term. Ovaries derived from the fetuses of known gestational age were either used for organ culture, or were fixed as controls. Other females were allowed to give birth and the ovaries of their progeny were also used for organ culture or as controls.

\section{Organ culture}

The technique used for culturing the ovaries has been published previously (BAKER and NEAL, I969, I972), and is similar to that employed by other investigators (see e. g. RYLE, this Symposium). However, the small ovaries were placed on blocks of gelled $2 \mathrm{p}$. roo agar within the petri dishes rather than on the usual stainless steel grids. The culture medium (consisting of Eagle's minimum essential medium with Earle's salts, supplemented with calf serum [20 p. Ioo $v / v]$, glutamine and antibiotics), has been shown to contain little or no gonadotrophic hormones (see BAKER, 1969). The petri dishes were placed in modified ' Kilner' preserving jars, gassed at $0.703 \mathrm{kgm} / \mathrm{cm}^{2}$ with 5 p. Ioo $\mathrm{CO}_{2}$ in air, and incubated at $37^{\circ} \mathrm{C}$. The culture medium was replaced every $3^{\text {rd }}$ or $4^{\text {th }}$ day.

\section{Hormones}

The hormones used in the present study were follicle stimulating hormone (NIH-FSH-S9) and luteinizing hormone (NIH-LH-Sr8), which were dissolved in Eagle's medium to a concentration of $10 \mathrm{mg} / \mathrm{ml}$. They were added to the culture dishes (to give a final concentration of $0.2 \mathrm{mg} / \mathrm{ml}$ ) on the first day of culture and immediately after each change of the support medium.

\section{Histology}

Ovaries derived from the organ cultures (usually still attached to the agar rafts), and also those recovered directly from the animal, were fixed in Bouin's aqueous fluid for 2-4 hours. They were subsequently dehydrated in a graded ethanol series, embedded in paraffin wax and serially sectioned at $6 \mu \mathrm{m}$. The sections were stained with Harris's haematoxylin and eosin and mounted with DPX.

( ${ }^{1}$ In this paper, the day of mating and/or appearance of the vaginal plug is taken to be day I of pregnancy, and the day of birth as day I post partum. 


\section{Design of experiments}

The normal development of the ovary in Schofield strain mice was assesed from an examination of serial sections of gonads fixed at two-day intervals from day 14 post conception $(p . c$.$) to$ day I 4 post partum $(p . p$.$) . These results were correlated with our previous findings on follicular$ growth and pre-ovulatory maturation of oocytes in these mice (BAKER and NeAL, I972; NeAL and BAKER, I973). Other ovaries derived from the same litters as the controls were used for organ culture at ages ranging from $\mathrm{I}_{4}$ days $p$. c. to $\mathrm{I}_{4}$ days $p . p$. : they were cultured for periods from 2 to $I_{4}$ days.

\section{RESULTS}

\section{Normal development of the ovary in vivo}

On the I4th day of gestation the ovaries of Schofield albino mice contain a mixed population of germ cells, the majority of which are ' resting' and dividing oogonia, although a small proportion have reached the leptotene or zygotene stages of meiotic prophase (fig. I). By the I6th day, the population of oogonia has declined and the early meiotic stages now predominate. From day I8 p.c. until shortly before birth, the population of germ cells remains fairly static, almost all the oocytes being at the pachytene stage (fig. 2). But by the time of birth these cells have progressed to the diplotene and dictyate stages (roughly equal numbers of each cell type). With the onset of the 3 rd day $p$. $p$. the entire ' stock' of oocytes have reached the dictyate stage and the majority are surrounded by a layer of flattened or cuboidal granulosa cells (primordial follicles; fig. 4).

The first signs of impending follicular growth involve the oocyte which grows markedly in size and gains a complete layer of cuboidal granulosa cells (stage II of follicular growth ; see MaULÉ:ON, I969). These oocytes begin to enlarge on day $3 p$. p., but they are not commonly encountered until day 7 , a time when the primordial follicles become more widely separated by proliferation of the ovarian stroma (fig. 9). The follicular wall subsequently becomes two-layered by mitotic division of the granulosa cells (day 7 onwards). By the I4th day a proportion of the follicles possess three or more layers of follicle cells and some show signs of cavitation (fig. Io). The most noteworthy change, however, consists in a further proliferation of stromal tissue such that the follicles become more widely separated. The full spectrum of follicular stages (up to Graafian) is found by day $2 \mathrm{I}$ p. p., although pre-ovulatory changes within the oocytes does not occur unless the animals are treated with exogenous gonadotrophins (BAKER and NEAL, I972 ; NEAL, and BAKER, I973).

\section{Development of mouse ovaries in organ culture}

The morphological appearance of ovaries cultured for 2 days from the I4th, I6th, or I8th days of gestation, closely resembles that of controls derived from fetuses aged I6, I 8 or 20 days $p$. c. (fig. I, 3 and 6). Similarly, gonads cultured from the I4th or I6th day to a time equivalent to day 2 or $3 p . p$. also show comparable stages of germ cell development to controls (fig. 4 and 5), although the total number of oocytes appears to be reduced. This is particularly true when culture is commenced on day $\mathrm{I} 4$, while culture from day I $8 p . c$. to day $5 p$. p. does not result in a reduction 
in the total population of germ cells (fig. 7). It would seem therefore that the diminution in the number of oocytes is due to a deficiency prior to the pachytene stage (see below).

Ovaries explanted on day I4 p. c. and cultured to a time equivalent to day $7 p$. $p$. also have fewer germ cells than controls (fig. 8). Furthermore, their development appears to be retarded in that fewer oocytes have commenced their growth phase, an essential pre-requisite for follicular growth (fig. 8 ; cf. fig. 9). The development of follicle and stromal cells is also retarded : the primordial follicles have few granulosa cells and the oocytes are crowded together (fig. 8). Such ovaries show a more severe retardation in development than those cultured from day 2 to day $7 p \cdot p$. (fig. II). The ovaries recovered from organ culture are consistently smaller than those in controls and are flattened, their long axes being in contact with the agar blocks used for supporting the tissue within the dishes.

Ovaries explanted on day $2 p . p$. and cultured to day I4 without the addition of exogenous gonadotrophins, differ considerably from controls (fig. I4). The oocytes show a normal pattern of development with the expected proportion undergoing the growth phase, but the number of follicle cells surrounding each oocyte is markedly reduced. Furthermore, the granulosa cells are much smaller than those in coeval controls : they have less cytoplasm and their nuclei stain more intensely with haematoxylin (fig. I4; cf. fig. Io). The ' growing' oocytes, together with a proportion of the small primordial follicles, are crowded together with few intervening granulosa cells. However, the whole group of oocytes is surrounded by a basement membrane and a number of small somatic cells. These structures are somewhat reminiscent of the polyovular follicles seen in the ovaries of such species as the opossum and hamster. A few large single-layered follicles can occasionally be found in the ovary, but development of the stroma seems to be inadequate and that of the theca is virtually absent.

The addition of $\mathrm{FSH}$ to cultures of post-natal mouse ovaries results in a partial, although incomplete, restoration of ovarian development. Thus ovaries cultured with exogenous FSH from day $2 p . p$. to day 7 are more comparable in appearance to the controls than are those where no hormones were added (fig. I2; cf. fig. II). Follicles with one or two layers of granulosa cells are numerous but many contain degenerating oocytes, especially those deep in the ovarian cortex. Although the development of follicles and stroma is clearly improved by the FSH treatment, the overall morphological appearance remains deficient when compared to the controls (fig. I2; cf. fig. 9). This is also true when the ovaries are cultured from day $2 p . p$. to a time equivalent to day I4 (fig. I5). Numerous enlarged oocytes are enclosed within follicles with a complete layer of granulosa cells but the theca does not develop. However, the granulosa cells have abundant cytoplasm and resemble comparable cells in controls (cf. culture without addition of hormones; see above).

The addition of $\mathrm{LH}$ to the organ cultures also improves the overall histological appearance of the gland (fig. 13 ). Ovaries cultured from day 2 to day $7 p$. $p$. with LH do not show the crowding of oocytes characteristic of hormone-free cultures : granulosa and thecal cells proliferate in response to the hormone but to a lesser extent than in vivo (fig. I3 ; cf. fig. Io). Follicles with two layers of granulosa cells are rare in the LH-treated ovaries and are absent from explants cultured to day I4 p. p. (fig. I6 ; cf. fig. Io). 


\section{DISCUSSION}

The results of the present study demonstrate that female germ cells can proceed through meiotic prophase in the absence of gonadotrophic hormones, results which confirm the findings of previous investigators (MARTINOVITCH, I938 ; WOLFF, I952 ; BORGHESE, and VENINI, I956 ; ODOR and BLANDAU, I97I). It would seem, therefore, that female germ cells are in some way ' $I$ rogrammed' such that the process is completed within the same time in organ culture as it is in vivo. The possibility cannot at present be excluded, however, that some factor (presumably hormonal) ' triggers' the differentiation of germ cells before the earliest stage at which we cultured the ovaries (I4 days $p$. c.). Since male germ cells in normal and chimaeric mice do not seemingly undergo meiotic prophase before puberty, this 'trigger' would have to operate after the onset of sexual differentiation in the male ( 13 days p.c.), or be specific for female germ cells. For the mouse, this possibility would be difficult to investigate since these early embryonic ovaries are difficult to handle in the procedures used for organ culture. It would need to be tested using species in which germ cells do not enter the prophase of meiosis until after birth (e. g. rabbit or hamster), a study currently being undertaken in our laboratory by $\mathrm{D}^{\mathrm{r}} \mathrm{S}$. CHALIONER.

Although precise counts of the numbers of germ cells have so far not been completed, a reduction in the population of oocytes occurs in organ culture which is not found in controls. Thus more germ cells survive culture from the 16 th day of gestation to day $3 p . p$. than from day 14 , and what appears to be the normal population is found following culture from day I $8 p . c$. It seems probable that this is due to either the lack of some trophic stimulus which normally maintains oogonia and promotes their division by mitosis, or their progression to the leptotene stage of meiotic prophase is partially blocked. Alternatively, the lack of a trophic stimulus may affect the development of granulosa cells such that oocytes fail to progress through the pachytene or diplotene stages. OHNo and SMrTh (r964) have postulated that oocytes which are surrounded by an inadequate number of granulosa cells undergo atresia at this critical stage.

In an attempt to determine which of these stages of germ cell differentiation (oogonia : oocytes at leptotene, or pachytene-diplotene) represents the critical stage in terms of germ cell depletion, ovaries were cultured from days 2 to $7 p$. $p$. with tritiated thymidine in the culture medium. It was found, however, that few of the oocytes survived the treatment, and that these cells were largely unlabelled. This result is not surprising since BAKER, MCLAREN (I973) have recently shown that mouse fetal germ cells are extremely sensitive to the low-energy $\beta$-radiation emitted by the isotope in vivo (see also BAKER, I97I). It is clear, therefore, that this problem will need to be resolved in a species whose germ cells are less radiosensitive than those in the mouse.

The early stages of follicular growth are generally believed to proceed normally in the absence of gonadotrophic hormones. This conclusion derives largely from studies involving hypophysectomized animals whose ovaries often contain pre-antral follicles (see Mauléon, I969). However, Eshkol, Lunenffeid and Peters (I97I), 
using an antiserum prepared against gonadotrophic hormones, showed that follicular growth in I-I5 day-old mice is abnormal in the absence of gonadotrophic hormones. When animals that had been pre-treated with the anti-gonadotrophin preparation were injected with human menopausal gonadotrophin (HMG : FSH + LH) normal follicular development was restored.

It has often been shown that organ cultures of mouse and rat ovaries contain few developing follicles unless gonadotrophins are added to the medium used to support the explants (e. g. LOSTROH, I959; VAN DE KERCKOVE, I959 ; PAVIC, I963 ; FAINSTAT, I968; ODOR and BLANDAU, I97I). The results of the present study not only confirm these observations for ovaries in organ culture, but also substantiate the importance of both FSH and LH in the normal process of follicular growth (EsHkol et al., I97I). Thus neither FSH nor LH alone can maintain follicular growth in organ culture to the point to which it occurs in vivo : FSH improves the appearance of the granulosa cells although their multiplication remains reduced, while $\mathrm{LH}$ maintains the morphology of the oocytes in these follicles. Neither hormone alone can cause differentiation of the theca, nor the full development of the ovarian stroma. It is hoped that further studies involving the addition of various combinations of hormones may throw further light on the factors controlling follicular growth, oocyte maturation, and atresia.

\section{ACKNOWLEDGEMENTS}

The expenses incurred in this study were defrayed out of a grant to T. G. B. by the Population Council, New York. The hormones were generously provided by the Endocrine study Section, National Institutes of Health, Bethesda, U. S. A.

\section{RÉSUMÉ́}

\section{INITIATION ET CONTRÔLE DE LA MÉIOSE}

\section{ET DE LA CROISSANCE FOLIICULAIRE DANS LES OVAIRES DE SOURIS}

Des ovaires de fœetus ou de nouveau-né (de $\mathrm{I}_{4}$ jours $p$. c. à $\mathrm{I}_{4}$ jours $p . p$.) prélevés sur des Souris de souche Schofield sont maintenus en culture d'organe pour des périodes allant de 2 à I4 jours. Les coupes histologiques de ces gonades sont comparées aux coupes de gonades témoin prélevées sur des animaux d’âge comparable.

Dans les ovaires de foetus la prophase méiotique se déroule de la même façon en culture et in vivo, mais le nombre de cellules germinales est réduit si l'ovaire est cultivé pendant une période critique (I 4-I 8 jours p.c.). Le développement de la granulosa, des cellules thécales et du stroma est retardé, si bien que l'ovaire est plus petit et que les ovocytes sont tassés les uns contre les autres.

Le déroulement de la croissance folliculaire est fortement retardé quand on cultive en milieu anhormonal. Ni FSH, ni LH seules ne sont capables de restaurer une croissance normale, mais chacune de ces deux hormones améliore divers aspects du processus complet. La présence simultanée de FSH et de LH est nécessaire pour que le développement normal de l'ovaire prépubère soit convenablement maintenu. 


\section{REFERENCES}

BAKER T. G., I969. The sensitivity of rat, monkey and human oocytes to $\mathrm{X}$ radiation in organ culture In : Radiation Biology of the Fetal and Juvenile Mammal. ed. M. R. Sikov and D. D. Mahlum, p. 955962. U. S. A. E. C. Conf-6905or.

BAKER T. G., I97I. Comparative aspects of the affects of radiation during oogenesis. Mutation Res. 11, 9-22.

Baker T, G., r972. Oogenesis and Ovarian Development. In : Reproductive Biology, ed. H. Balin and S. R. Glasser, p. 398-437. Amsterdam : Excerpta Medica.

Baker T. G., McLaren A., r973. The effect of tritiated thymidine on the developing oocytes of mice. J. Reprod. Fert., in press.

Baker T. G., Neal P., t969. The effect of X-irradiation on mammatian oocytes in organ culture Biophysik, 6, 39-45.

BAKER T. G., NEAL P., I972. Gonadotrophin-induced maturation of mouse Graafian follicles in organ culture. In : Oogenesis, ed. J. D. Biggers and A. W. Schuetz, p. 377-396. Baltimore : University Park Press.

BEN-Or S., 1968. Morphological and functional development of the ovary of the mouse. I. Morphology and histochemistry of the developing ovary in normal conditions and after FSH treatment. J.Embryol. exp. Morph., 11, I-II.

Borghese E., VENINI M. A., r956. Culture in vityo di gonadi embryonali di Mus musculus. Symposia Genetica, 5, 69-83.

Eshrol A., Lunenfeld B., Peters H., 1971. Ovarian development in infant mice. In : Gonadotrophins and Ovarian Development, ed. W. R. Butt, A. C. Crooke and M. Ryle, p. 249-258. Edinburgh : Livingstone.

Fainstat T., rg68. Organ culture of postnatal rat ovaries in chemically defined medium. Fert. Steril. 19, 317-338.

LostroH A. J., r959. The response of ovarian explants from post-natal mice to gonadotrophins. Endocrinology, 65, $\mathrm{x} 24-\mathrm{r} 32$.

Martinovitch P. N., 1938. The development in vitro of the mammalian gonad. Ovary and ovogenesis. Proc. $R$. Soc., B, 125, 232-249.

MaUlÉon P., 1969. Oogenesis and folliculogenesis. In : Reproduction in Domestic Animals, ed. H. H Cole and P. T. Cupps, 2nd ed. p. I87-215. New York : Academic Press.

Neal P., Baker T. G., 1973. Response of mouse ovaries in vivo and in organ culture to pregnant mare's serum gonadotrophin and human chorionic gonadotrophin. I. Examination of critical time intervals $J$. Reprod. Fert., in press.

Odor D. L., Blandau R. J., r971. Organ cultures of fetal mouse ovaries. I. Light microscope structure. Am.J.Anat., 131, 387-4I4.

Онло S., Sмiтн J.-B., r964. Role of fetal follicular cells in meiosis of mammalian oocytes. Cytogenetics, 3, 324-333.

PAvic D., 1963. The effect of gonadotrophic hormones on young rat ovaries in organ culture. J. Endocr., 28, $531-538$.

VAN DE KERCKove, 1959. L'ovaire périnatal de la Souris blanche en culture organotypique. C. $R$. Ass. Anat., 104, 754-759.

Wolff E., 1952. Sur la différenciation sexuelle des gonades de Souris explantées in vitro. C. R. Acad. Sci., 284, I YI2-I7I4. 


\section{PLATE I}

FIG. I

Mouse ovary on the I4th day of gestation. The germ cells are largely oogonia although some cells have progressed to the leptotene stage of meiotic prophase. Mag. $=\times 400$.

\section{FIG. 2}

Ovary removed from a mouse on the 18 th day of gestation. The germ cells have reached the pachytene stage. Mag. $=\times 75^{\circ}$.

FIG. 3

Ovary cultured from day I4 p.c. to day I8 p.c. Germ cell differentiation is similar to that in controls (see figure $2:$ Mag. $=\times 400)$.

FIG. 4

Control ovary from a 2-day-old mouse. The oocytes have reached the dictyate stage of prophase and are enclosed within primordial follicles. Mag. $=\times 400$.

\section{FIG. 5}

Ovary cultured from day I4 p.c. to a time equivalent to day $2 p . p$. The oocytes (at the dictyate stage) are similar to those in controls, but fewer oocytes have enlarged (cf. fig. 4). Mag. = $\times 400$.

\section{PLANCHE I}

FIG. I

Ovaire à I4 jours de gestation. Les cellules germinales sont surtout des ovogonies, quelques cellules sont au stade leptotène de la prophase méiotique.

FIG. 2

- Ovaire à I 8 jours de gestation. Les cellules germinales ont atteint le stade pachytène.

FIG. 3

Ovaire cultivé de $\mathbf{I} 4$ jours $p . c$. à $\mathbf{I} 8$ jours $p . c$. La différenciation des cellules germinales est comparable à celle des témoins (fig. 2).

$$
\text { FIG. } 4
$$

Ovaire d'une Souris de 2 jours. Les ovocytes ont atteint le stade dictyé de la prophase méiotique et sont enfermés dans des follicules primordiaux.

$$
\text { FIG. } 5
$$

Ovaire cultivé de I4 jours $p$. $c$. à l'équivalent de 2 jours $p$. $p$. Les ovocytes (stade dyctyé) sont comparables à ceux des témoins, mais moins d'ovocytes ont subi leur phase de croissance. 

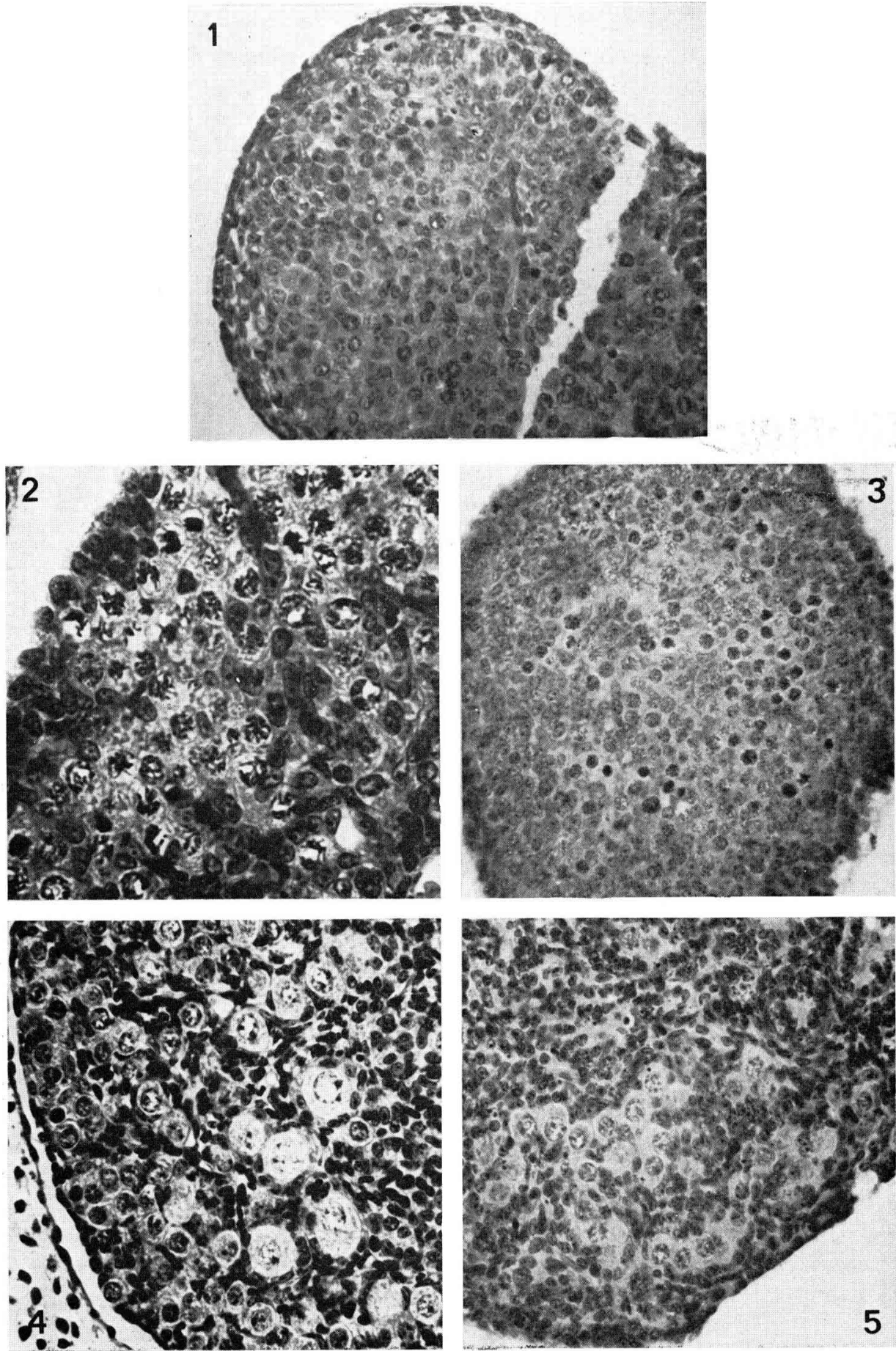

T. G. BAKER and P. NEAL 


\section{PLATE II}

FIG. 6

Ovary explanted on day 14 p.c. and cultured to day 20 p.c. As in coeval controls, the oocytes have largely reached the diplotene stage of meiotic prophase with a few at the dictyate stage. Mag. $=\times 400$.

\section{FIG. 7}

Ovary cultured from day 18 p.c. to day 3 p. p. Ovarian development is similar to that in controls (see Fig. 4). Mag. $=\times 400$.

Fig. 8

Culture set up on day 14 p.c. and fixed on day 7. Fewer oocytes have commenced the growth phase than would be expected from controls (cf. Fig. 9), and the oocytes are crowded together. Mag. $=\times 400$.

\section{FIG. 9}

Ovary on the 7th day post-partum. A proportion of the oocytes have enlarged and become surrounded by a complete layer of granulosa cells. Two-layered follicles are occasionally encountered. Mag. $=\times 400$.

Fig. 10

Ovary of a 14 day old mouse. Two and three layered follicles are commonly encountered. Mag. $=\times 400$.

\section{PLANCHE II}

Fig. 6

Òvaìre cultivé de 14 jours p.c. à 20 jours p.c. Comme chez les témoins d'âge identique, les ovocytes ont en grande partie atteint le stade diplotène de la prophase méiotique, quelques-uns sont au stade dictyé.

\section{FIG. 7}

Ovaire cultivé de 18 jours p.c. à 3 jours p.p. Le développement ovarien est" le même que chez les témoins (Fig. 4).

$$
\text { Fig. } 8
$$

Ovaire cultivé de 14 jours p.c. à 7 jours p.p. Beaucoup moins d'ovocytes ont commencé la phase de croissance que chez les témoins (Fig. 9) et les ovocytes sont tassés les uns contre les autres.

\section{FIG. 9}

Ovaire 7 jours p.p. Une partie des ovocytes a subi la phase de croissance et s'entoure d'une couche complète de cellules de la granulosa. On observe parfois des follicules à deux couches.

FIG. 10

Ovaire d'une souris de 14 jours. On rencontre fréquemment des follicules à deux et trois couches. 

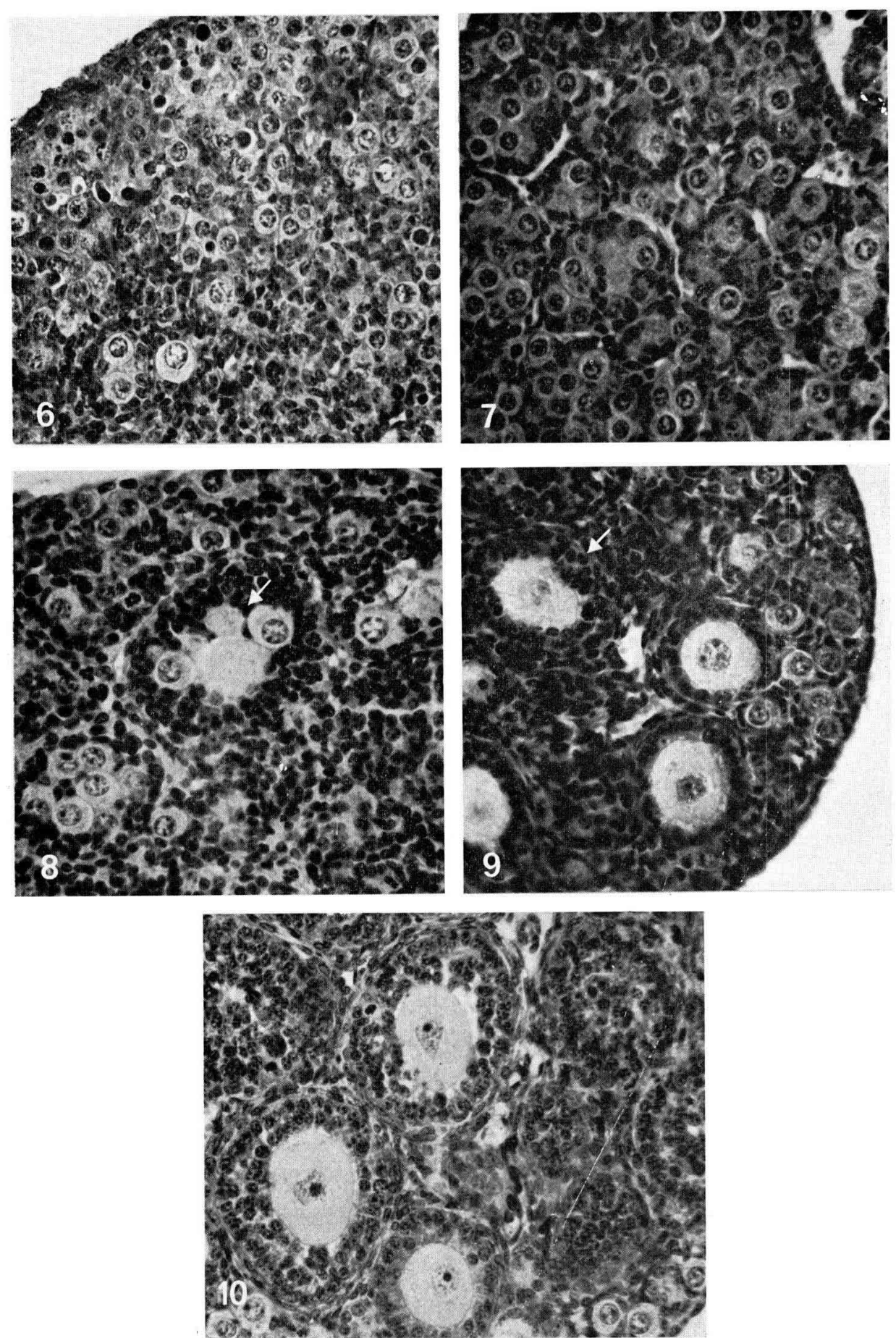

T. G. BAKER and P. NEAL 
FIG. 11

Ovary explanted on day 2 and cultured to day 7. The proportion of small versus "large " oocytes in primordial follicles is similar to that in controls (Fig. 9), but the granulosa cells are indistinct. Mag. $=\times 400$.

FIG. 12

Similar culture to that in figure 11, but treated with FSH. The granulosa cells are maintained more comparably to controls. Some of the large follicles appear empty or contain degenerating oocytes $(\swarrow)$. Mag. $=\times 400$.

Fig. 13

Ovary cultured from day 2 to day 7 p.p. with LH. The gonad appears similar to controls although follicular growth is not so well advanced : two layered follicles are absent. Mag. $=\times 400$.

FIG. 14

Gonad cultured from day 2 to day 14 p.p. without gonadotrophic hormones. Many enlarged oocytes are clumped together with few intervening follicle cells (cf. control ; Fig. 10). Mag. $=\times 400$.

FIG. 15

Similar culture to figure 14 , but with FSH in the medium. Few of the largest follicle stages are represented; otherwise the appearance is similar to controls. Mag. $=\times 400$.

Fig. 16

Ovary cultured in the presence of LH from day 2 to 14 p.p. The appearance is generally similar to controls although development of the follicles is somewhat retarded. Mag. $=\times 400$.

\section{PLANCHE III}

FIG. 11

Ovaire cultivé de 2 jours à 7 jours p.p. La proportion de petits ovocytes par rapport aux "grands " est la même que dans l'ovaire témoin (Fig. 9), mais on ne voit pas les cellules de la granulosa.

FIG. 12

Même culture que la figure 11, mais traitée avec FSH. Les cellules de la granulosa sont maintenues et sont plus comparables à celles des témoins. Quelques grands follicules sont vides ou contiennent des ovocytes en dégénérescence $(\swarrow)$.

FIG. 13

Ovaire cultivé de 2 jours à 7 jours p.p. en présence de LH. La gonade apparaît comparable à la gonade témoin, bien que la croissance folliculaire soit moins avancée : il n'y a pas de follicules à 2 couches.

Fig. 14

Gonade cultivée de 2 jours à 14 jours p.p. sans hormones gonadotropes: Beaucoup des "grands" ovocytes sont tassés les uns contre les autres avec peu de cellules folliculaires pour les séparer (cf. témoin, Fig. 10).

FIG. 15

Même culture que sur la figure 14, mais avec FSH dans le milieu. Peu des stades des plus grands follicules sont représentés ; autrement l'aspect est le même que pour les témoins.

FIG. 16

Ovaire cultivé de 2 jours à 14 jours p.p. en présence de LH. Aspect grossièrement comparable au témoin bien que le développement des follicules soit un peu retardé. 

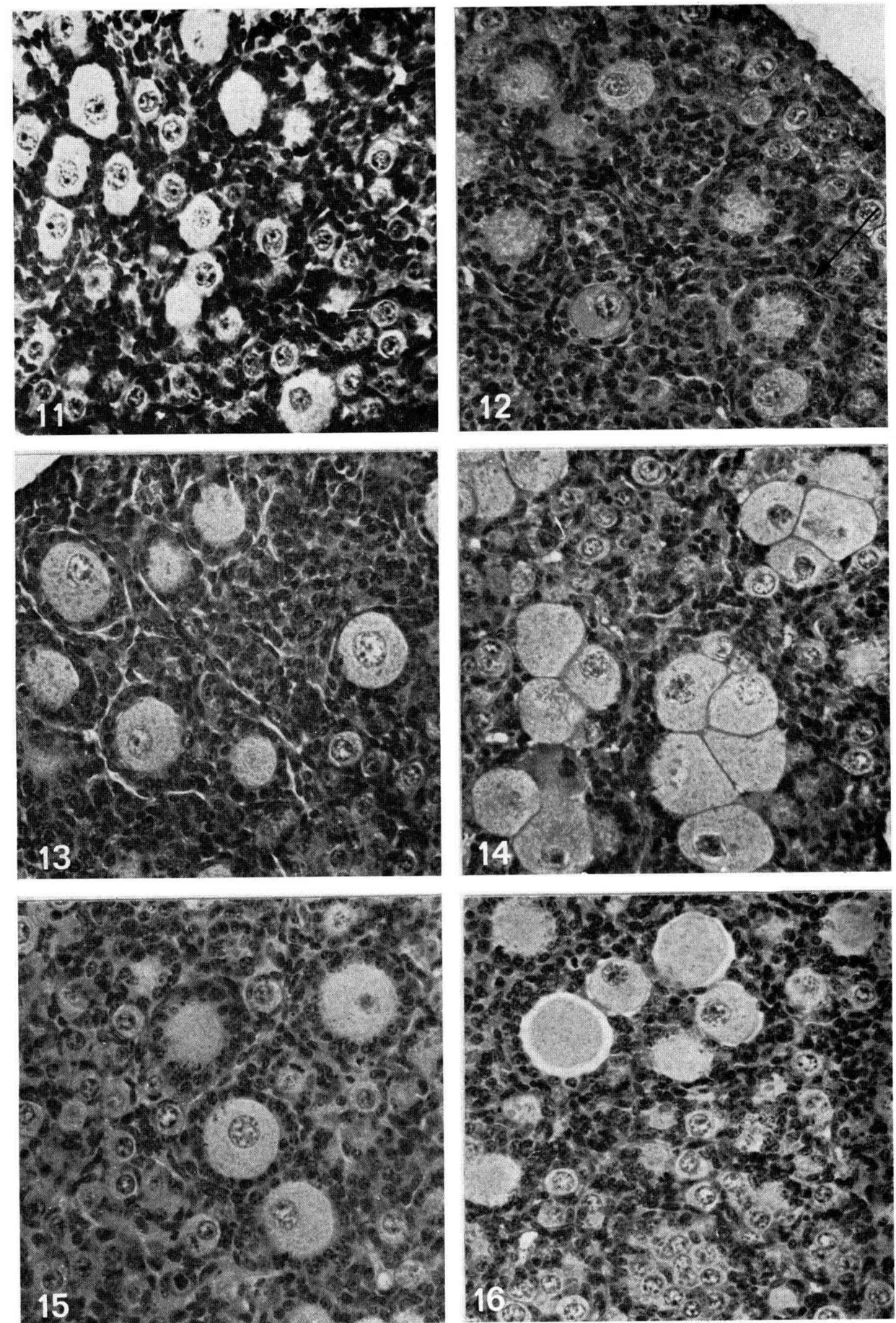

T. G. BAKER and P. NEAL 